\title{
Assessing Subaquatic Mass Movement Hazards: an Integrated Observational and Hydrodynamic Modelling Approach
}

\author{
Love Råman Vinnå $^{1,2}$ (D) Damien Bouffard ${ }^{2}$ (D) - Alfred Wüest ${ }^{1,2}$ (D) \\ Stéphanie Girardclos ${ }^{3,4}$ (D) N Nathalie Dubois ${ }^{5,6}$
}

Received: 27 March 2020 / Accepted: 31 August 2020 /

Published online: 10 September 2020

(C) The Author(s) 2020

\begin{abstract}
High-resolution lake and reservoir bathymetric surveys can pinpoint locations that may experience underwater landslides (subaquatic sedimentary mass movements). These can pose a risk to underwater and shoreline infrastructure. This paper outlines an approach for using spatial variation in sedimentary patterns to identify areas susceptible to subaquatic mass movements in lakes and reservoirs. This study focusses on Lake Biel (Switzerland), which has experienced a protracted history of upstream alteration of river flow. Altered flow patterns increase risk of unstable sedimentary features and subaquatic mass movements. Data from sediment traps and cores, Acoustic Doppler Current Profilers and results from a 3D hydrodynamic model gave a consistent picture of spatial and temporal variation in weather-related sedimentation. Erosion caused by short-term rain events contributes the largest proportion of sediments to the lake. Strong rain events combine with typical wind patterns to drive lake circulation. The net effect results in preferential sedimentation onto a steeply sloping shelf prone to subaquatic slides. The integrated approach outlined here incorporates short- and long-term sediment dynamics to provide a systematic assessment of lake sedimentation and potential mass movement hazards. This research represents a first step in developing a risk-evaluation tool for aquatic hazard evaluation.
\end{abstract}

Keywords Subaquatic mass movements · Coastal infrastructure - Weather-dependent sedimentation $\cdot$ River redirection $\cdot$ Geological engineering $\cdot$ Risk evaluation tool

Electronic supplementary material The online version of this article (https://doi.org/10.1007/s11269-02002660-y) contains supplementary material, which is available to authorized users.

\section{Love Råman Vinnå}

love.ramanvinna@eawag.ch

Damien Bouffard

damien.bouffard@eawag.ch

Extended author information available on the last page of the article 


\section{Introduction}

Shorelines of both inland and coastal waters are often highly altered geomorphological environments that accommodate major infrastructure including harbours, roads, railways, underwater pipelines, transmission cables and water intakes. Slope failures resulting in massive, rapid downslope movement of sediment, also known as subaquatic mass movements, can damage this infrastructure and disrupt lake ecosystems. Coastal examples include the destruction of the entire dock area in the town of Valdes, Alaska (Coulter and Migliaccio 1966), a landfill collapse at an airport in Nice, France (Kopf et al. 2010) or the recent 2020 destruction of eight houses in Alta, Norway caught on camera (e.g. https://www.nytimes. com/2020/06/05/world/europe/norway-landslide.html). These events can damage submarine infrastructure such as communication cables as in the case of the Grand Banks mass movement outside Newfoundland and the hyperpycnal flow off the coast of Taiwan (Piper and Aksu 1987 ; Fine et al. 2005; Carter et al. 2012). Subaquatic mass movements can also cause major property damage around lakes. Multiple houses and quays were lost around Lake Geneva, Switzerland during the 18th and 19th centuries (Forel 1892, p.148-151). Subaquatic mass movements are known to have disrupted settlements surrounding Lake Geneva even during prehistoric times. A tsunami caused by a mass movement may have caused a gap in occupation around the lake during the early bronze age ( 1700 BC; Kremer et al. 2014). A rock fall caused a delta collapse and resultant tsunami of sufficient height to pass over the city walls of Geneva during early medieval times (563 AD; Kremer et al. 2012). More recent examples include construction induced slides in Lake Lugano, which damaged the Lugano city port in 1992 (Hofmann and Filella 1999), and the Horgen slide of 1875 (Kelts and Hsü 1980), which swept a newly constructed railway into Lake Zürich.

Modification of rivers has caused a net global decrease in suspended sediment reaching the oceans and a net increase in sediment settling behind dams and in lakes (Syvitski et al. 2005). A 1714 project redirecting the Kander River into Lake Thun, Switzerland for example increased the occurrence of subaquatic mass movements in this lake. Risks associated with increased sediment supply highlight the need for evaluating downstream effects prior to largescale alteration of river flow (Wirth et al. 2011).

Subaquatic mass movements concentrate in areas with steep slopes and thick, fine-grained sediment supplied at high rates. Examples include fjords, deltas and submarine canyons (Lee et al. 2007). Delta regions in lakes often experience subaquatic slides both in the form of canyon confined turbidity currents (Lambert and Giovanoli 1988) and more destructive delta collapse events (Blass et al. 2005; Kremer et al. 2012). Slope failures occur once downslope driving forces overcome stabilizing forces acting to resist the slope's shear strength. Failures can arise spontaneously due to accumulation of critical sediment masses, or they can be triggered by external forces such as earthquakes/rockslides, storms, gas/groundwater eruption, water level fluctuations or blasting during construction (Lee et al. 2007; Sassa et al. 2009). Slopes with an inclination $>\sim 20^{\circ}$ are prone to failure given sufficient sediment loading, while slopes $<\sim 20^{\circ}$ generally require external forces to trigger a slide (Strasser et al. 2011).

Assessing risk associated with subaquatic mass movements is difficult and depends on accurate prediction of mechanisms that trigger slope failure and likely locations of failure (Harbitz et al. 2014). Recent advances in bathymetric sensing (e.g. multi-beam and LIDAR surveys) have enabled more detailed imaging of high-risk areas. Basin scale evaluation can include methods for estimating risk areas and damages of different risk factors (Strasser et al. 2011; Strupler et al. 2019). In addition to high resolution bathymetric data, these approaches 
can also benefit from detailed, in situ information on sediment properties such as grain size distributions and mobilization strength. Surveys however can usually only gather a limited number of high quality samples. Along with cost limitations, lake sediments often contain dissolved gasses prone to expansion upon removal from the lake bottom (Sassa et al. 2009). These factors require identification of high-risk areas prior to sample collection as part of an integrated risk assessment for subaquatic mass movements.

This research used an interdisciplinary hydrodynamic and sedimentological approach to identify areas at risk for subaquatic mass movement. Interpreting sedimentary processes requires detailed understanding of deposition from random perturbations and that which occurs on different decadal to annual time scales (Finger et al. 2006; Righetti et al. 2011; Schimmelpfennig et al. 2012; Tananaev 2012; Perga et al. 2018). This research conducted annual water column monitoring using sediment traps, acoustics and thermistors. Sediment cores provided decadal scale depositional data. These lines of empirical information were supplemented with output from a high-resolution hydrodynamic model (Delft3D-Flow). The combined datasets revealed processes driving lake sedimentation and areas at risk for future subaquatic mass movements.

\section{Material and Methods}

\subsection{Study Site}

The meso-eutrophic, warm, monomictic Lake Biel $\left(7^{\circ} 10^{\prime} \mathrm{E}, 47^{\circ} 5^{\prime} \mathrm{N}\right)$ lies within the western part of the Swiss Plateau between the Jura Mountains and the foothills of the European Alps (Fig. 1b, c). The lake holds a volume of $1.18 \mathrm{~km}^{3}$, has a total surface area of $39.3 \mathrm{~km}^{2}$, reaches a maximum depth of $74 \mathrm{~m}$ and has an uncommonly short hydraulic residence time of $\sim 58$ days. Lake bathymetry includes slopes exceeding $10^{\circ}$ angle along a majority of the shoreline (Baran 2017; Råman Vinnå et al. 2017b). The adjacent City of Biel depends on Lake Biel as its main source of drinking water. In late 2009, a subaquatic slope failure in Lake Biel (Fig. 1d enlargement) interrupted drinking water treatment (Råman Vinnå et al. 2017b).

Lake Biel offers a classic example of a freshwater body strongly impacted by modifications to its hydrological catchment. The unusual hydrodynamics of this medium-sized lake resulted from the "Jura Water Corrections" project initiated in 1868 (Vischer 2003; Nast 2006; Dubois et al. 2020). Seeking to limit floods and increase agricultural production, this project redirected the Aare River via the Hagneck channel (Fig. 1c) into Lake Biel. The project also widened the lake's main outflow, the Nidau-Büren channel and constructed the Thielle and Broye channels, which connected upstream Lakes Neuchâtel and Murten to Lake Biel (Fig. 1c). These measures dramatically increased Lake Biel's sedimentation rate by an order of magnitude from $\sim 0.1$ to $\sim 1.1 \mathrm{~cm} \mathrm{yr}^{-1}$ (Santschi and Schindler 1977; Thevenon et al. 2013; Jeannet et al. 2013) and reduced the hydraulic residence time from $\sim 253$ to $\sim 58$ days (Liechti 1994). Aare River inflow, which drains productive farmland, caused Lake Biel to shift from mesotrophic to meso-eutrophic by the mid-twentieth century (Roth and Geiger 1972; Wright et al. 1980; Dubois et al. 2020). Several upstream dams/lakes in the Aare drainage area (Fig. 1b, c) trap the bulk of sediment and warm cold waters from upstream glaciers (Wright et al. 1980; Thevenon et al. 2013). A sub-catchment to the Aare, the Saane River (Sarine in French, Fig. 1b), likely provides most of the suspended load to Lake Biel (Thevenon et al. 2013; Råman Vinnå et al. 2018). 
a)

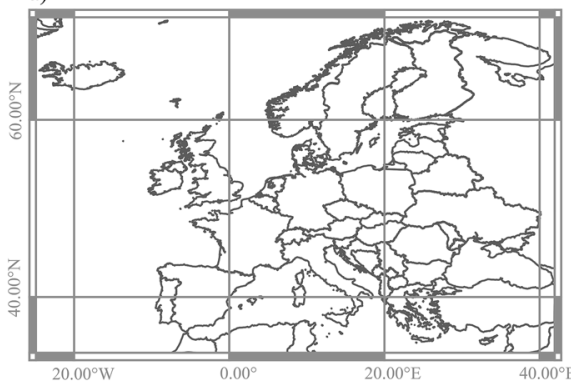

b)

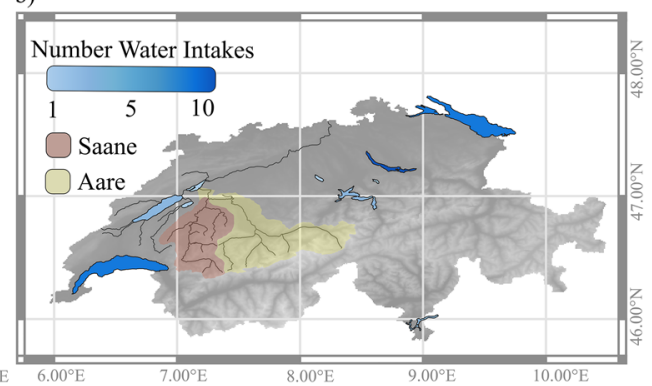

d)
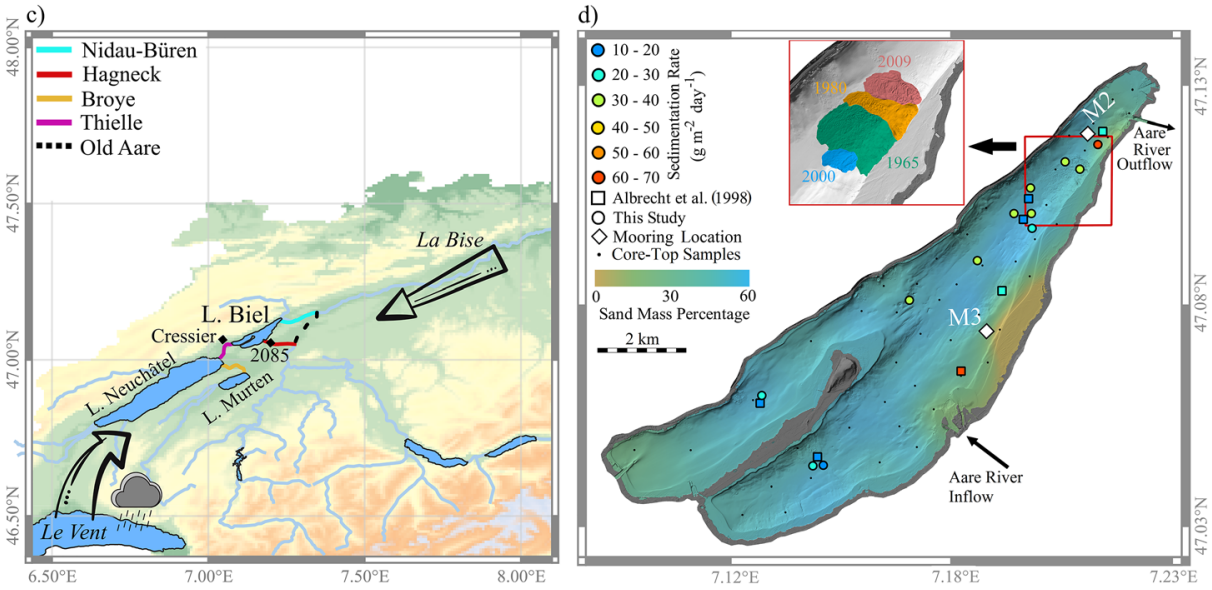

Fig. 1 a Location of Switzerland. b Number of lake-based drinking water intakes in Switzerland (SVGW 2016), water pathways connected to Lake Biel (black lines), and upstream Saane and Aare drainage basins (colourcoded). c Prevailing wind directions on the Swiss Plateau (arrows), measurement stations (diamonds) and alterations to river flow (channels marked in colour) implemented by the Jura Water Corrections project (details in Dubois et al. 2020). d Lake Biel spatial sedimentation patterns with interpolated mass percentage of sand $(63$ to $2000 \mu \mathrm{m})$ from core-top samples (points) in surface sediment, sedimentation rates derived from gravity cores (circles this study covering 1986 to 2010/15, squares from Albrecht et al. 1998 covering 1986 to 1993/97) and location of moorings (white diamonds). The red insert shows the subaquatic mass movement complex (Dubois et al. 2020)

As the Aare River enters Lake Biel, its riverine plume usually sinks into the thermocline in summer. During winter months, the denser river water can penetrate past the thermocline into the hypolimnion (Albrecht 1999; Råman Vinnå et al. 2018). Near-field intrusion depends on density differences between river and lake water as well as river discharge. Wind-driven lake circulation determines the final fate of the intruding river plume. The surrounding topography favours prevailing wind directions either from the southwest (Le Vent) or northeast ( La Bise). These generate the wind field over the lake and drive circulation (Fig. 1c; Råman Vinnå et al. 2017a).

\subsection{Measurements and Models}

This study interpreted both empirical and model data on Lake Biel water and sediment dynamics. Field monitoring occurred from May 2013 to September 2015 (2.4 years) over three month intervals with two to four days gaps between deployments. Parts of the field 
campaign is described in Råman Vinnå et al. (2017a). Here we limit our analysis and discussion to previously unpublished data from this campaign. Described data were collected at moorings M2 and M3 (47 and $28 \mathrm{~m}$ depth, respectively) along the main riverine flow path (Fig. 1d).

The main sedimentary input to Lake Biel derives from the Aare River. We therefore measured suspended sediment concentration (SSC) in the Aare River $\sim 1 \mathrm{~km}$ upstream of Lake Biel at station 2085 (Fig. 1c) with a Solitax TS-Line turbidity sensor (0.001 to 4000 NTU/FTU, accuracy $<1 \%$ ). Turbidity values were fitted to SSC estimates from water samples (filter pore size $<1 \mu \mathrm{m}$, Appendix Fig. A1) collected monthly by the Federal Office of the Environment (FOEN) monitoring program. The Aare River's total suspended sediment load (Fig. 2a) was estimated by multiplying discharge rates by SSC converted from turbidity (equation in Appendix Fig. A1).

Temperature, current, particle fluxes and sedimentation rates were measured using moorings extending from the lake bottom to its surface. Sediment cores from locations throughout Lake Biel provided additional long-term constraints. Temperature was monitored with Vemco Minilog II-T and TR-1060 loggers at vertical intervals of 0.5 to $6 \mathrm{~m}$. Acoustic Doppler Current Profilers (ADCPs) of the Teledyne RD Instruments Workhorse Sentinel series provided current measurements and detection of the sediment-laden river plume. The ADCPs were deployed along the lake bottom and set at 300 and $600 \mathrm{kHz}$ (for M2 and M3, respectively). Appendix Text A1 describes the compensation for echo intensity signals loss.

Gravity cores (46 to $120 \mathrm{~cm}$, Fig. 1d, Appendix Table A1), core-top samples ( $2 \mathrm{~cm}$, Fig. 1d, Appendix Table A2) and sediment traps (two $80 \mathrm{~cm}$ long, $65 \mathrm{~cm}^{2}$, vertically installed PVC pipes; Appendix Table A3) were used to quantify sedimentation. Cores were dated based on ${ }^{137} \mathrm{Cs}$ radionuclide activity measured from 5 to $10 \mathrm{~g}$ of freeze-dried sediment (cores BIE-14-52 and BIE-14-61; Dubois et al. 2020). Nuclides were measured using a high-purity Canberra Germanium Well Detector following methods described in Thevenon et al. (2013). The sedimentation rates were calculated from the core top (year of coring) to the depth of the 1986 Chernobyl ${ }^{137} \mathrm{Cs}$ peak $\left(S R, \mathrm{~m} \mathrm{yr}^{-1}\right)$. Mass accumulation rate $(M A R)$ in cores was obtained using the mean water content $(W C ; 63 \%)$ of all cores (Appendix Table A1) and the sediment dry density $\left(D D=2650 \mathrm{~kg} \mathrm{~m}^{-3}\right)$ following calculations by Steinsberger et al. (2017):

$$
M A R=S R * D D *(100-W C) * 1000 / 365(\mathrm{~g} \mathrm{~m}-2 \text { day }-1)
$$
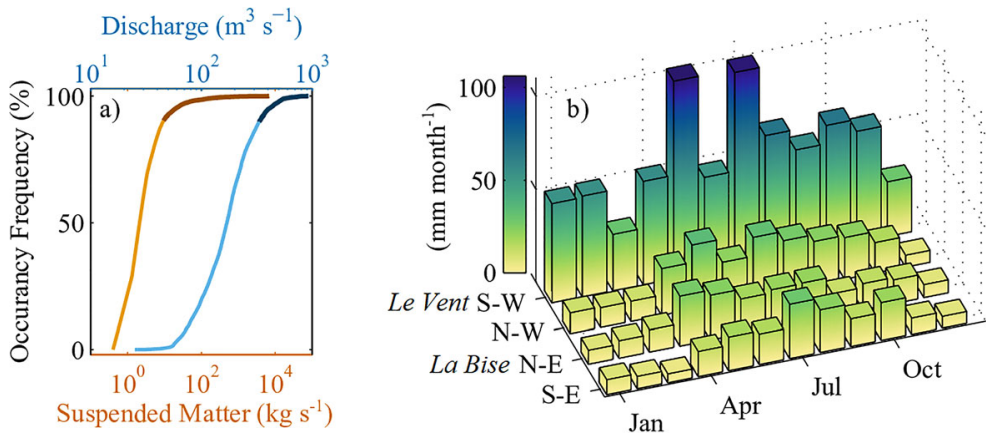

Fig. 2 a Aare River (station 2085, Fig. 1c) discharge and total load of suspended sediment between May 2013 and September 2015 with uppermost $10 \%$ marked by darker shading. b Annual mean precipitation in the Saane watershed (Fig. 1a) sorted for wind direction with heavy rain during Le Vent (wind from the southwest). Data provided by the Cosmo-2 weather model 
MAR was also calculated from the total suspended sediment load observed in the Aare by dividing the incoming load by the lake surface area. This approach excluded other sources and outflows. Grain size distributions (clay, silt and sand) in sediment traps and core-top samples were measured by laser diffraction using a Malvern Mastersizer $2000(0.02$ to $2000 \mu \mathrm{m})$. Samples were dispersed in $\mathrm{NaPO}_{4}$ prior to analysis and disaggregated by brief ultra-sonication. Each sample was measured at least three times.

The spatially-resolved $\left(2.2 \times 2.2 \mathrm{~km}^{2}\right)$ meteorological COSMO-2 model (http://www. cosmo-model.org) provided hourly-resolved wind and rain data within the Saane River catchment (Fig. 1b). Previous studies have validated this meteorological model for the region surrounding Lake Biel (Hug et al. 2010; Weusthoff et al. 2010). Modelled rain was clustered relative to wind direction on a pixel-by-pixel basis. Figure $2 \mathrm{~b}$ displays rain as annual means at monthly resolution. Hourly resolved wind data were acquired between May 2013 and September 2015 at Cressier weather station (Fig. 1c).

The three-dimensional model Delft3D-Flow version 4.001 (http://oss.deltares. $\mathrm{nl} /$ web/delft3D) was used to examine the circulation inside Lake Biel as well as Aare River intrusions into the lake. This was done with idealized cases as well as atmospheric and river data. Model setup, validation and rotational corrections are described in Råman Vinnå et al. (2017a). Two idealized cases represent the dominant wind fields over Lake Biel, La Bise from the northeast and Le Vent from the southwest. To mimic wind at Cressier station (Fig. 1c, mean speed $\sim 2 \mathrm{~m} \mathrm{~s}^{-1}$ from May 2013 to September 2015), directions were set to randomly varying from 20 to $70^{\circ}$ ( La Bise) and 200 to $250^{\circ}$ ( Le Vent), with diurnal varying speed from 0 (midnight) to $4 \mathrm{~m} \mathrm{~s}^{-1}$ (midday). Results are shown hereunder at steady state. In order to reconcile measurements (Fig. 3) with largescale circulation patterns (Fig. 4), the spatial distribution of the Aare plume in Lake Biel was investigated during two high sediment load events (sediment load $>1000 \mathrm{~kg} \mathrm{~s}^{-1}$ at station 2085) on July 29th and August 11th 2014. Modelling of circulation during these events used spatially-varying atmospheric forcing inputs from the COSMO-2 weather model, a nonreactive numerical tracer was used to detect the plume pathway. Figure 4 $\mathrm{c}, \mathrm{d}$ show the sequential, temporal dispersion of the river plume in both the horizontal and vertical directions along with colour coded variation in wind forcing. Each step in colour represents a 12-h interval. A vertical temperature profile from the deepest location in the lake sampled on July 16th, 2014 (model initialization date) provided constraints on initial thermal stratification assumptions used in all model runs.

\section{Results and Discussion}

\subsection{Riverine Sediment Input and Weather Patterns}

From May 2013 to September 2015, $>80 \%$ of the suspended sediment supplied by the Aare entered Lake Biel on intervals representing less than $10 \%$ of the total monitoring time (Fig. 2a). Data did not show clear links between high SSC and large discharge events. Discharge and turbidity data also varied independently with large discharge events uncoupled to turbidity spikes (Appendix Fig. A2). Large rivers originating as outflows from lakes show similarly chaotic patterns wherein tributaries downstream from lake outflow supply the majority of sediments (Tananaev 2012). Upstream of Lake Biel, lakes/reservoirs along the Aare River trap sediments originating from glaciers in 

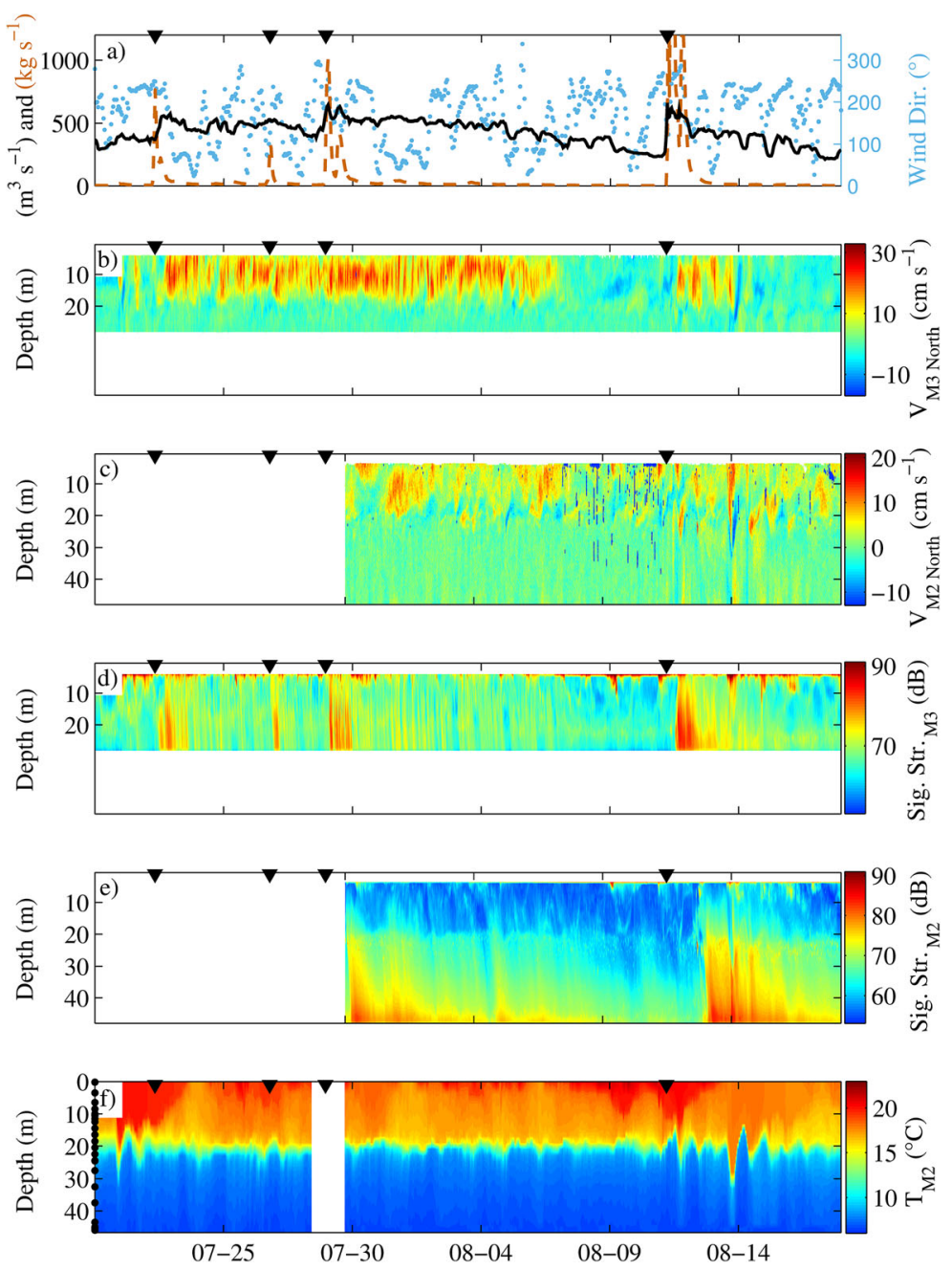

Fig. 3 Aare River intrusions into Lake Biel in July and August 2014. a River discharge (black) and suspended sediment (orange) at station 2085 as well as wind direction at Cressier station (blue dots; Fig. 1c). Northward current speed at b mooring M3 and $\mathbf{c}$ mooring M2. Mean four beam echo return signal strength indicating elevated levels of suspended sediment at d M3 and e M2. f Temperature at M3 with logger vertical location marked by black circles (left scale). Black triangles show times of high suspended sediment concentration (SSC) at station 2085. White gaps in $\mathbf{b}$ to $\mathbf{f}$ are due to missing data between deployments (horizontally) or difference in station depth (vertically)

headwater regions (Matter and Sturm 1982). The data support previous interpretations that the Saane River, a tributary to the Aare (Fig. 1b) which contains no dams in its lower reaches, supplies the majority of suspended sediment to Lake Biel (Thevenon et al. 2013; Råman Vinnå et al. 2018).

The irregularity of high SSC events indicates atmospheric precipitation events as the likely driver of erosion and sediment transport into the Saane River. The majority of intense precipitation events in the Saane catchment showed close temporal connection to Le Vent winds (Fig. 2b). From May 2013 to September 2015, we also detected a 1 to 

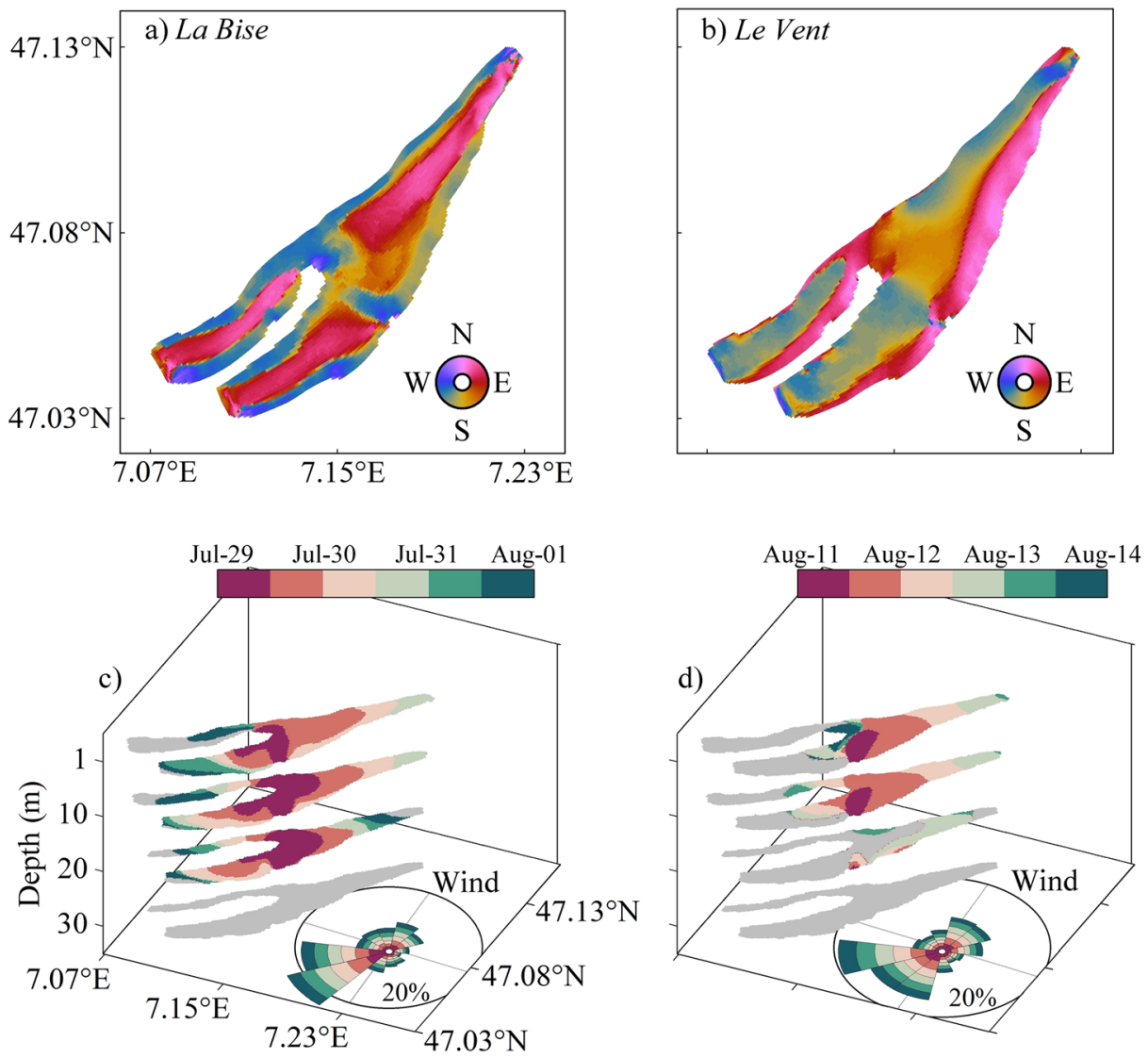

Fig. 4 Three-dimensional modelled wind-induced currents in Lake Biel and dispersion of Aare River intrusions. Epilimnion median steady-state current direction for La Bise (a) and Le Vent (b) with varying diurnal wind speeds of 0 (midnight) to $4 \mathrm{~m} \mathrm{~s}^{-1}$ (midday). Dispersion of river intrusion on c July 29th and d August 11th, 2014, colour-coded toward horizontal passive tracer dispersion over a $12 \mathrm{~h}$ interval. Wind rose shows corresponding probability of the wind direction over the lake surface

$40 \mathrm{~h}$ delay between precipitation in the Saane catchment and high SSC readings at station 2085 (total load $>1000 \mathrm{~kg} \mathrm{~s}^{-1}$ ). In addition to wind direction-dependent rain patterns (Fig. 2b), station 2085 showed a strong seasonal signal in the total MAR from the Aare. From May 2013 to September 2015, more sediment was supplied in summer (mean $=42$ and standard deviation $\pm 126 \mathrm{~g} \mathrm{~m}^{-2}$ day $^{-1}$; April to September) than in winter (mean $=7 \pm 10 \mathrm{~g} \mathrm{~m}^{-2}$ day $^{-1}$; October to March). Annual MAR amounted to $24 \pm$ $91 \mathrm{~g} \mathrm{~m}^{-2} \mathrm{day}^{-1}$. This estimate generally resembled rates reported by Santschi and Schindler (1977) of $14.2 \mathrm{~g} \mathrm{~m}^{-2}$ day $^{-1}\left(2.04 \times 10^{8} \mathrm{~kg} \mathrm{yr}^{-1}\right)$ obtained from monthly water sample-based mass balance of inflows and outflows from 1973 to 74 . Together, these data suggest an increase in sediment supply to Lake Biel between the two periods (197374 and 2013-15). The higher temporal resolution data reported here have benefited from advances in optical measurements of turbidity. Given contrasting data collection methods and the highly variable nature of SSC, the apparent increase in sediment supply may reflect different measurement techniques or actual changes in sediment supply. 


\subsection{Sedimentation Patterns and Plume Pathway}

Lake Biel exhibited diverse sedimentation patterns. For the period 1986-2010/15, the central basin and northeastern parts of the lake (29-62 $\mathrm{g} \mathrm{m}^{-2}$ day $^{-1}$; Fig. 1d) showed enhanced MAR relative to the two southwestern facing arms (16-24 $\mathrm{g} \mathrm{m}^{-2}$ day-1). Albrecht et al. (1998) observed an increase in MAR from 8 to 16 to $13-21 \mathrm{~g} \mathrm{~m}^{-2}$ day ${ }^{-1}$ (cores 93-01, 94-07, 94-4 and 96-01) from 1963 to 1986 to 1986-1993/97. The largest increase occurred close to the shallow eastern shelf (core 93-01). Albrecht et al. (1998) attributed these patterns to intensified erosion in the catchment. The higher MAR levels reported here suggest high erosion rates or events have continued in the catchment since the 1990s. Exact long-term causes for the erosion however remain uncertain.

Sediment in Lake Biel consists primarily of silt-sized particles ( 2 to $63 \mu \mathrm{m}$ ) which account for an increasing percentage of mass towards deeper parts of the lake (Fig. 1d, Appendix Table A3). Shallow parts of the lake host the largest mass percentage of sand-sized particles (63 to $2000 \mu \mathrm{m}$; Appendix Table A3). These increase along the shallow eastern shoreline north of the Aare inlet (Fig. 1d) indicating high rates of sedimentation. Weiss (1979) also describes the notable absence of carbonate material (indicating an Alpine origin) in sediments forming the shallower eastern shelf.

Sedimentation along Lake Biel's eastern shoreline likely reflects transport by the main river plume. This plume carries a high sediment load generated by precipitation in the Saane River catchment during Le Vent winds. Previous studies tracking the Aare sediment plume have detected two drastically different patterns. First, the plume may follow the shoreline towards northeast (Nydegger 1976; Wright and Nydegger 1980). Second, Albrecht et al. (1999) observed a different plume path flowing into the central parts of the lake.

We evaluated our interpretation by using the three-dimensional Delft3D-Flow model with an idealized wind field (section 2.2), which included La Bise (from the northeast, Fig. 4a) and Le Vent (from the southwest, Fig. 4b). During La Bise, the model predicted an epilimnion gyre rotating clockwise in central parts of the lake (Fig. 4a). The model predicted a counterclockwise gyre during Le Vent winds (Fig. 4b). These circulation patterns (available online at: http://meteolakes.ch/\#!/hydro/biel; Baracchini et al. 2020) either carry the river plume towards the lake center in the case of La Bise, or towards the City of Biel in the northeast in the case of Le Vent.

Wright and Nydegger (1980) and Nydegger (1976) used sedimentary analysis, aerial photographs and a rotating table model to interpret plume dynamics but excluded wind effects. They describe the river water in the lake as a shoreline following plume forced by inflow and outflow induced currents under the influenced of the Coriolis force. Albrecht et al. (1999) unexpectedly observed a tracer cloud entering into the central part of the lake basin, the cloud gradually migrated along northwestern shore towards the lake outflow. This suggests their experiments were performed during the clockwise and counter-clockwise circulation events detected in Lake Biel by this study.

Field monitoring supports the flow and sedimentation patterns generated by the model described above. Figures 3 and 4 show intrusion of the river into the lake during a period of high river discharge and SSC in the summer of 2014. River water within the lake was detected as unusually strong currents at the M3 mooring (plume velocities up to $30 \mathrm{~cm} \mathrm{~s}^{-1}$; Fig. 3b) and a strong ADCP echo signal. Stations M2 and M3 also recorded high concentrations of suspended particles (Fig. 3d, e). The plume, which flowed above the thermocline, could be traced from M3 to M2 during Le Vent winds. The 3D model generated a spatial pathway for 
the river plume during the July 29th (Fig. 4c) and August 11th 2014 events (Fig. 4d). As illustrated by the wind roses in Fig. 4c, d, winds blew predominantly from the southwest during and following these events. The passive tracer in the model spread mainly towards northeast above the thermocline as a result of the counter-clockwise central lake gyre. For both events, the plume reached the northern-most parts of Lake Biel within $\sim 1$ day. For the July 29th event, the plume appeared at M2 $25 \mathrm{~h}$ after the event according to the model and $\sim 22 \mathrm{~h}$ after the event according to field monitoring data. For the August 11th event, the plume appeared at M2 $23 \mathrm{~h}$ after the event according to the model and $\sim 29 \mathrm{~h}$ after the event according to field monitoring data. In summary, Le Vent winds, which blow during raininduced erosion events in the Saane catchment, drive the river plume towards the northeast thereby focussing deposition along the shallow eastern shelf and in the central basin. La Bise winds override Coriolis forcing and drive a plume carrying less sediment into central parts of the lake.

\subsection{Consequences for Subaquatic Mass Movements}

The wind-driven focusing of sedimentation in Lake Biel typically diverts the SSC-laden Aare riverine plume along a shallow shelf northeast of the inflow (Fig. 1d). A large amount of sediment accumulates on the shelf and steep slope areas. South of M2, the shallow area of the shelf becomes narrower towards its terminus (Fig. 1d, red frame). Remaining river water cascades into deeper regions of the lake towards M2. This steep, narrow shelf region has experienced multiple subaquatic mass movements over the last fifty years (Dubois et al. 2020). No major sediment failures have been detected closer to the Aare inlet. If such events did occur, they have been covered by recent sediment from the Aare plume. Gases in upper sedimentary layers prevent acoustic imaging and detection of possible sediment failure surfaces (Dubois et al. 2020). Figure 3e shows sediment accumulation from the Aare plume at station M2. M2 experienced a MAR only $40 \%\left(23 \mathrm{~g} \mathrm{~m}^{-2}\right.$ day ${ }^{-1}$, trap mean in Appendix Table A3) as large as that measured at M3 $\left(61 \mathrm{~g} \mathrm{~m}^{-2}\right.$ day $\left.^{-1}\right)$. M2 also recorded lower plume velocities relative to those measured at M3 making the plume harder to identify in the absence of settling particles (Fig. 3b, c). Lower velocities permit greater settling of clay-sized particles but M2 and M3 sediment traps recorded similar proportions of sand (Appendix Table A3). This indicates resuspension of larger particles along the shallow eastern shelf. Together with the subaquatic mass movements evident along the northern edge of the shelf (Fig. 1d, red frame), M2 data and model results for the plume indicate that mass accumulated along this steepened area may destabilize sediment in this region. Wind focusing of sedimentation combined with the increased sediment load from the redirection of the Aare thus work together to form this area at risk for subaqueous mass movements. Our results support previous findings showing that increased sediment loads from river flow alteration have increased the risk of slides (Lee et al. 2007; Wirth et al. 2011).

A better understanding of the role of weather events in generating high sediment loads can inform risk modellers towards water resource management. Deltas fed by periodically heterogeneous sediment supplies may not build a uniform, fan-shaped sedimentary deposit. In these systems, deposition depends on temporal relations between the sedimentary processes of erosion and transport (e.g. climate and currents). Assessment of future river engineering projects and mitigation of past river alteration effects should include consideration of river discharge, sediment supply and factors that influence how sediment is distributed throughout the lake basin. Given its dependence on weather events, the risk of subaquatic mass 
movements will also evolve in response to ongoing climate change. Shifts in local weather patterns may modify catchment erosion rates, wind and other factors influencing deposition in the lake basin. Strasser et al. (2007) demonstrated the short geological time scales necessary to shift sedimentary regimes in previously glacially-influenced lakes. Given a history of alteration, lakes like Lake Biel are susceptible to changes in their headwaters or catchment erosion that may overload previously stable depositional features.

\section{Conclusion}

This paper described sedimentation patterns in a lake substantially affected by hydrological changes in its watershed and tributaries. Using numerical modelling and in situ monitoring, we detected links between meteorological events, lake circulation and sedimentary deposition. The sediment supply to Lake Biel depends on major precipitation events in the Saane catchment, which feeds the Aare River. These precipitation events occurred primarily during Le Vent winds (from the southwest), which drive counter-clockwise currents inside Lake Biel. High sediment supply and lake currents coincide to deposit sediment along a shallow shelf region prone to subaquatic mass movements over the last century. Our results demonstrate multiple, overlapping causes, including long-term effects of large infrastructure projects, in generating subaquatic mass movements. Risk management and mitigation strategies should incorporate understanding of these factors, especially high sedimentation rates, in determining risks associated with aquatic infrastructure.

An integrated approach combining meteorology, hydrology, hydrodynamics and sedimentology can inform risk assessment for subaquatic mass movements in lakes. This approach should specifically include the following steps: (1) identify major sediment sources and likely erosion areas, (2) determine temporal trends for high sediment load events, (3) identify atmospheric events or forcing associated with such events and (4) identify circulation patterns that transport sediment towards steeply sloping depocenters. Methods for accomplishing these tasks should incorporate (i) measurements of suspended sediments, discharge and temperature in inflowing rivers, (ii) meteorological measurements/models, (iii) 2- or 3D hydrodynamic modelling of currents and sediment dynamics and (iv) in situ sediment cores and water column measurements of temperature, currents and sediment load. Data from (iii) and (iv) can be collected independently and are not required in initial stages of risk evaluation. Management authorities may elect not to use these sources but they improve accuracy of risk assessment. Once high-risk areas are identified, more targeted efforts can be used to assess sediment and slope stability. Precise sampling, for example, could further refine hazard models of the areas identified by the methods described here.

Acknowledgments Open Access funding provided by Lib4RI - Library for the Research Institutes within the ETH Domain: Eawag, Empa, PSI \& WSL. We are thankful to Andreas Hirt, Roland Käser and Markus Wyss of ESB for constructive feedback and collaboration. We thank the Swiss Federal Office of Meteorology and Climatology (MeteoSwiss) for COSMO model data (http://www.meteoswiss.admin.ch/home/services-andpublications/produkte.html), the Hydrology Department at the Swiss Federal Office for the Environment (FOEN) for river data (flow, turbidity, suspended solids; http://www.bafu.admin.ch/umwelt/index.html?lang= en), the Swiss Federal Office of Topography (SwissTopo). We also thank Flavio Anselmetti and Michael Hilbe of the Quaternary Geology and Paleoclimatology research group at the University of Bern for providing bathymetric data (https://www.geo.apps.be.ch/de). Arrows and clouds in Fig. 1c were designed by Freepik. We also thank Adrien Gaudard, Gyan Louis Rusconi-Rodrigues, Isabel Kiefer, Jonathan Schenk, Michael Plüss, 
Michael Schurter, Natacha Tofield-Pasche, Alois Zwyssig, Alfred Lück, Silvia Bollhalder-Lück, Oscar Sepúlveda Steiner, Robert Schwefel, Sébastien Lavanchy, Theo Baracchini, Vincent Nouchi and Zoran Kaufmann for valuable assistance in the field. Thanks to Marvin Rabold, Irene Brunner, Alfred Lück and Maria-Inés Haldman for laboratory analyses and dating of sediment cores.

Funding This manuscript is part of the "Hydrodynamic modeling of Lake Biel for optimizing the Ipsach drinking water intake" project funded by Energy Service Biel.

Data Availability For external data sources see Acknowledgments section, for measurements analysed in this manuscript contact corresponding authors.

\section{Compliance with Ethical Standards}

Conflict of Interest The authors have no conflict of interest to declare.

Open Access This article is licensed under a Creative Commons Attribution 4.0 International License, which permits use, sharing, adaptation, distribution and reproduction in any medium or format, as long as you give appropriate credit to the original author(s) and the source, provide a link to the Creative Commons licence, and indicate if changes were made. The images or other third party material in this article are included in the article's Creative Commons licence, unless indicated otherwise in a credit line to the material. If material is not included in the article's Creative Commons licence and your intended use is not permitted by statutory regulation or exceeds the permitted use, you will need to obtain permission directly from the copyright holder. To view a copy of this licence, visit http://creativecommons.org/licenses/by/4.0/.

\section{References}

Albrecht A (1999) Transport of radiocobalt discharged by the Müehleberg nuclear reactor in the aquatic systems of the Aare river and Lake Biel (Switzerland). Hydroecologie Appliquee 11(1):1-28. https://doi.org/10.1051 /hydro:1999001

Albrecht A, Reiser R, Lück A, Stoll JA, Giger W (1998) Radiocesium dating of sediments from lakes and reservoirs of different hydrological regimes. Environ Sci Technol 32(13):1882-1887. https://doi.org/10.1021 les970946h

Albrecht A, Goudsmit G, Zeh M (1999) Importance of lacustrine physical factors for the distribution of anthropogenic 60Co in Lake Biel. Limnol Oceanogr 44:196-206. https://doi.org/10.4319/lo.1999.44.1.0196

Baracchini T, Wüest A, Bouffard D (2020) Meteolakes: an operational online three-dimensional forecasting platform for lake hydrodynamics. Water Res 172:115529. https://doi.org/10.1016/j.watres.2020.115529

Baran R (2017) Projektbericht: Bielersee - LiDAR-Daten und Digitales Geländemodell in Kombination mit Echolot-Daten, Alpine Airborne HydroMapping, Innsbruck, Österreich, 6 Februar 2017

Blass A, Anselmetti FS, Grosjean M, Sturm M (2005) The last 1300 years of environmental history recorded in the sediments of Lake Sils (Engadine, Switzerland). Eclogae Geol Helv 98(3):319-332. https://doi. org/10.1007/s00015-005-1166-5

Carter L, Milliman JD, Talling PJ, Gavey R, Wynn RB (2012) Near-synchronous and delayed initiation of long run-out submarine sediment flows from a record-breaking river flood, offshore Taiwan. Geophys Res Lett 39(12). https://doi.org/10.1029/2012GL051172

Coulter HW, Migliaccio RR (1966) Effects of the earthquake of March 27, 1964, at Valdez, Alaska: Chapter C in The Alaska earthquake, March 27, 1964: effects on communities. U.S. Government Printing Office, pp 136. https://doi.org/10.3133/pp542C

Dubois N, Råman Vinnå L, Rabold M, Hilbe M, Anselmetti FS, Wüest A et al (2020) Subaquatic slope instabilities: the aftermath of river correction and artificial dumps in Lake Biel (Switzerland). Sedimentology 67(2):971-990. https://doi.org/10.1111/sed.12669

Fine IV, Rabinovich AB, Bornhold BD, Thomson RE, Kulikov EA (2005) The Grand Banks landslide-generated tsunami of November 18, 1929: preliminary analysis and numerical modeling. Mar Geol 215(1-2):45-57. https://doi.org/10.1016/j.margeo.2004.11.007 
Finger D, Schmid M, Wüest A (2006) Effects of upstream hydropower operation on riverine particle transport and turbidity in downstream lakes. Water Resour Res 42(8):W08429. https://doi.org/10.1029/2005WR004751

Forel FA (1892) Le Léman (vol 1). Ed. Rouge, Lausanne (Switzerland), 539 pp

Harbitz CB, Løvholt F, Bungum H (2014) Submarine landslide tsunamis: how extreme and how likely? Nat Hazards 72(3):1341-1374. https://doi.org/10.1007/s11069-013-0681-3

Hofmann A, Filella M (1999) Transport of suspended matter in the hypolimnion of Lake Lugano: a comparison of field observations and model predictions. J Great Lakes Res 25(4):865-882. https://doi.org/10.1016 /S0380-1330(99)70784-7

Hug C, Kaufmann P, Ruffieux D (2010) Verification of COSMO-2 with independent data from a wind profiler. COSMO Newsletter No 10(6):64-69

Jeannet A, Corella JP, Reusch A, Kremer K, Girardclos S (2013) Lake Biel sediment record during the last 7500 years and impact of the Aare river deviation in 1878 AD, vol 15, pp 4027. Presented at the EGU general assembly 2013

Kelts K, Hsü KJ (1980) Resedimented facies of 1875 Horgen slumps in Lake Zurich and a process model of longitudinal transport of turbidity currents. Eclogae Geol Helv 73(1):271-281. https://doi.org/10.5169 /SEALS-164954

Kopf AJ, Kasten S, Blees J (2010) Geochemical evidence for groundwater-charging of slope sediments: the Nice Airport 1979 landslide and tsunami revisited. In: Mosher DC, Shipp RC, Moscardelli L, Chaytor JD, Baxter CDP, Lee HJ, Urgeles R (eds) Submarine mass movements and their consequences. Springer Netherlands, Dordrecht, pp 203-214. https://doi.org/10.1007/978-90-481-3071-9_17

Kremer K, Simpson G, Girardclos S (2012) Giant Lake Geneva tsunami in AD 563. Nat Geosci 5(11):756-757. https://doi.org/10.1038/ngeo1618

Kremer K, Marillier F, Hilbe M, Simpson G, Dupuy D, Yrro BJF et al (2014) Lake dwellers occupation gap in Lake Geneva (France-Switzerland) possibly explained by an earthquake-mass movement-tsunami event during early bronze age. Earth Planet Sci Lett 385:28-39. https://doi.org/10.1016/j.epsl.2013.09.017

Lambert A, Giovanoli F (1988) Records of riverborne turbidity currents and indications of slope failures in the Rhone delta of Lake Geneva. Limnol Oceanogr 33(3):458-468. https://doi.org/10.4319/lo.1988.33.3.0458

Lee HJ, Locat J, Desgagnes P, Parsons J, McAddoo B (2007) In: Nittrouer CA, Austin JA, Field ME, Kravitz JH, Syvitski JPM, Wiberg PL (eds) Submarine mass movements on continental margins, in continental margin sedimentation: from sediment transport to sequence stratigraphy. Blackwell Publishing Ltd., Oxford

Liechti P (1994) L'état des lacs en Suisse. Cahier de l'Environnement, 237, Office Federal de l'Environnement, des Forêts et du Paysage (OFEFP), Berne, Suisse, pp 159

Matter A, Sturm M (1982) Sedimentologische Untersuchungen in den grossen Berner seen: Brienzer-, Thunerund Bielersee. Mitteilungen der Naturforschenden Gesellschaft in Bern. Neue Folge 39:59-73. https:/doi. org/10.5169/seals-318473

Nast M (2006) Terre du lac, l'histoire de la correction des eaux du Jura. Verein Schlossmuseum Nidau

Nydegger P (1976) Strömungen in seen: Untersuchungen in situ und an nachgebildeten Modellseen. Beitr Geol Schweiz 66:141-177

Perga M, Bruel R, Rodriguez L, Guénand Y, Bouffard D (2018) Storm impacts on alpine lakes: antecedent weather conditions matter more than the event intensity. Glob Chang Biol 24(10):5004-5016. https://oi. org/10.1111/gcb.14384

Piper DJW, Aksu AE (1987) The source and origin of the 1929 grand banks turbidity current inferred from sediment budgets. Geo-Mar Lett 7(4):177-182. https://doi.org/10.1007/BF02242769

Råman Vinnå L, Wüest A, Bouffard D (2017a) Physical effects of thermal pollution in lakes. Water Resour Res 53(5):3968-3987. https://doi.org/10.1002/2016WR019686

Råman Vinnå L, Bouffard D, Dubois N, Hilbe M, Käser R, Wüest A (2017b) Seewasserentnahme im Bielersee Gibt es eine ideale position? Aqua \& Gas - Fachzeitschrift Für Gas, Wasser Und Abwasser 97(9):14-20

Råman Vinnå L, Wüest A, Zappa M, Fink G, Bouffard D (2018) Tributaries affect the thermal response of lakes to climate change. Hydrol Earth Syst Sci 22:31-51. https://doi.org/10.5194/hess-22-31-2018

Righetti M, Toffolon M, Lucarelli C, Serafini M (2011) Sediments as tracers for transport and deposition processes in peri-alpine lakes: a case study. J Hydrol 411(1-2):1-11. https://doi.org/10.1016/j.jhydrol.2011.08.018

Roth H, Geiger W (1972) Brienzersee, Thunersee, and Bielersee: effects of exploitation and eutrophication on the salmonid communities. J Fish Res 29(6):755-764

Santschi PW, Schindler PW (1977) Chemical and geochemical studies of Lake Biel I. A mass balance for Lake Biel and its implications for the rates of erosion of the drainage area. Aquat Sci 39(2):182-200. https://doi. org/10.1007/BF02502668

Sassa K, Canuti P, International Consortium on Landslides (eds) (2009) Landslides: disaster risk reduction. Presented at the United Nations world conference on disaster reduction. Springer, Berlin 
Schimmelpfennig S, Kirillin G, Engelhardt C, Nützmann G (2012) Effects of wind-driven circulation on river intrusion in Lake Tegel: modeling study with projection on transport of pollutants. Environ Fluid Mech 12(4):321-339. https://doi.org/10.1007/s10652-012-9236-5

Steinsberger T, Schmid M, Wüest A, Schwefel R, Wehrli B, Müller B (2017) Organic carbon mass accumulation rate regulates the flux of reduced substances from the sediments of deep lakes. Biogeosciences 14(13):32753285. https://doi.org/10.5194/bg-14-3275-2017

Strasser M, Stegmann S, Bussmann F, Anselmetti FS, Rick B, Kopf A (2007) Quantifying subaqueous slope stability during seismic shaking: Lake Lucerne as model for ocean margins. Mar Geol 240(1-4):77-97. https://doi.org/10.1016/j.margeo.2007.02.016

Strasser M, Hilbe M, Anselmetti FS (2011) Mapping basin-wide subaquatic slope failure susceptibility as a tool to assess regional seismic and tsunami hazards. Mar Geophys Res 32(1-2):331-347. https://doi.org/10.1007 /s11001-010-9100-2

Strupler M, Anselmetti FS, Hilbe M, Kremer K, Wiemer S (2019) A workflow for the rapid assessment of the landslide-tsunami hazard in peri-alpine lakes. Geol Soc Lond Spec Publ:SP500-2019-166. https://doi. org/10.1144/SP500-2019-166

SVGW (2016) dataset: "Statistische Erhebungen der Wasserversorgungen in der Schweiz, Betriebsjahr 2015"

Syvitski JPM, Vörösmarty CJ, Kettner AJ, Green P (2005) Impact of humans on the flux of terrestrial sediment to the global coastal ocean. Science 308(5720):376-380. https://doi.org/10.1126/science.1109454

Tananaev NI (2012) Hysteresis effect in the seasonal variations in the relationship between water discharge and suspended load in rivers of permafrost zone in Siberia and Far East. Water Res 39(6):648-656. https://doi. org/10.1134/S0097807812060073

Thevenon F, Wirth SB, Fujak M, Poté J, Girardclos S (2013) Human impact on the transport of terrigenous and anthropogenic elements to peri-alpine lakes (Switzerland) over the last decades. Aquat Sci 75(3):413-424. https://doi.org/10.1007/s00027-013-0287-6

Vischer DL (2003) Die Geschichte des Hochwasserschutzes in der Schweiz. Berichte des BWG, Serie Wasser, Nr. 5, 61-70, Bern

Weiss HP (1979) Die Oberflächensedimente des Bielersees. Eclogae Geol Helv 72(2):407-424. https://doi. org/10.5169/seals-164844

Weusthoff T, Ament F, Arpagaus M, Rotach MW (2010) Assessing the benefits of convection-permitting models by neighborhood verification: examples from MAP D-PHASE. Mon Weather Rev 138(9):3418-3433. https://doi.org/10.1175/2010MWR3380.1

Wirth SB, Girardclos S, Rellstab C, Anselmetti FS (2011) The sedimentary response to a pioneer geoengineering project: tracking the Kander River deviation in the sediments of Lake Thun (Switzerland). Sedimentology 58(7):1737-1761. https://doi.org/10.1111/j.1365-3091.2011.01237.x

Wright RF, Nydegger P (1980) Sedimentation of detrital particulate matter in lakes: influence of currents produced by inflowing rivers. Water Resour Res 16(3):597-601. https://doi.org/10.1029/WR016i003p00597

Wright RF, Matter A, Schweingruber M, Siegenthaler U (1980) Sedimentation in Lake Biel, an eutrophic, hardwater lake in northwestern Switzerland. Schweiz Z Hydrol 42(2):101-126

Publisher's Note Springer Nature remains neutral with regard to jurisdictional claims in published maps and institutional affiliations.

\section{Affiliations}

\section{Love Råman Vinnå $^{1,2} \cdot$ Damien Bouffard ${ }^{2} \cdot$ Alfred Wüest $^{1,2} \cdot$ Stéphanie Girardclos $^{3,4}$. Nathalie Dubois ${ }^{5,6}$}

1 Physics of Aquatic Systems Laboratory - Margaretha Kamprad Chair, Institute of Environmental Engineering, École Polytechnique Fédérale de Lausanne, Lausanne, Switzerland

2 Eawag, Swiss Federal Institute of Aquatic Science and Technology, Surface Waters - Research and Management, Kastanienbaum, Switzerland

3 Department of Earth Sciences, University of Geneva, Geneve, Switzerland

4 Institute for Environmental Sciences, University of Geneva, Geneve, Switzerland

5 Department of Earth Sciences, ETH Zürich, Zürich, Switzerland

6 Eawag, Swiss Federal Institute of Aquatic Science and Technology, Surface Waters - Research and Management, Dübendorf, Switzerland 